\title{
PENGARUH PENGGUNAAN KNEE DECKER TERHADAP NYERI LUTUT PADA PENGAYUH BECAK DI PASAR KLEWER
}

\author{
Cica Trimandasari, Prasetyo Catur Utomo, Muh Syaiful Akbar
}

Kementerian Kesehatan Politeknik Kesehatan Surakarta Jurusan Ortotik Prostetik

\begin{abstract}
Elastic Knee Decker, Rickshaw Peddlers, Knee Pain. Knee pain is a sore knee pain in the knee joint that can be known by everyone of all ages. Most of the illnesses can be at home, there are some conditions that require medical, such as surgery or which can cause prolonged illness, damage to the joints, and severe defects if not damaged. The purpose of this study is to find out how effective the decrease of pain in the use of elastic knee decker on pedicab driver in klewer market Surakarta. This type of research is experimental with one group pretest-podt test design, where there is only one group of conscientious subjects to be observed. In this study 20 respondents were given treatment in the form of use of elastic knee decker tool for 20 days. The results of this study indicate that there is an effect of the use of knee decker to decrease the degree of pain in pedicab drivers in the market klewer, with the results of analysis value $p=0,000$ ( $p<0.05), z=-4.041 a$. The conclusions of this study indicate that the use of elastic knee decker has an influence in decreasing the degree of knee pain in rickshaw peddlers in the market klewer Surakarta.
\end{abstract}

Keyword : Elastic Knee Decker, Rickshaw Peddlers, Knee Pain.

Abstrak : Elastis Deker Lutut, Pengayuh Becak, Nyeri Lutut. Nyeri lutut adalah Sakit lutut adalah nyeri pada sendi lutut yang dapat dialami oleh semua orang dari segala usia. Sebagian besar sakit lutut yang terjadi dapat ditangani sendiri di rumah, tetapi ada beberapa kondisi yang membutuhkan penanganan medis, seperti operasi atau yang bisa menyebabkan nyeri berkepanjangan, kerusakan pada sendi, dan bahkan cacat jika tidak ditangani secara khusus. Tujuan dari penelitian ini adalah untuk mengetahui seberapa besar efektif penurunan nyeri dalam penggunaan elastic knee decker pada pengayuh becak di pasar klewer Surakarta. Jenis penelitian ini adalah eksperimental dengan rancangan one group pretest-post test design, dimanan hanya terdapat satu kelompok subjek teliti yang akan diobservasi. Dalam penelitian ini 20 responden diberikan perlakuan berupa penggunaan alat elastic knee decker selama 20 hari. Hasil dari penelitian ini menunjukkan bahwa terdapat pengaruh penggunaan knee decker terhadap penurunan derajat nyeri pada pengayuh becak di pasar klewer, dengan hasil analisis nilai $p=0,000(p<0,05), z=-4,041 a$. Simpulan penelitian ini menunjukkan bahwa penggunaan elastic knee decker memilki pengaruh dalam penurunan derajat nyeri lutut pada pengayuh becak di pasar klewer Surakarta.

Kata Kunci : Elastis Deker Lutut, Pengayuh Becak, Nyeri Lutut. 


\section{PENDAHULUAN}

Pada masa yang semakin modern ini perkembangan transportasi baik itu darat, laut, maupun udara berkembang dan berevolusi semakin baik. Semakin baik dan canggihnya trasnsportasi modern saat ini lambat-laun akan mengalahkan transportasi tradisional yang ada. Namun, ada beberapa transportasi tradisional yang masih bertahan hingga kini salah satunya adalah becak Salah satu alat transportasi tradisional ini masih diminati sebagai kendaraan umum masyarakat. Salah satu lahan besar bagi tukang becak untuk mengais rejekinya adalah di pasar klewer yang menjadi pusat tekstil terbesar di kota solo (teras solo, 2015).

Seperti data yang didapat dari salah seorang basis pengayuh becak bernama kawit yang berusia 70 tahun di pasar klewer Surakarta tercatat ada 75 becak yang mangkal di basis pasar klewer pada saat sebelum tragedi kebakaran pasar terjadi, namun saat ini setelah tragedi itu terjadi pengayuh becak yang ada hanya sekitar 50 becak saja yang mangkal di pasar klewer sementara Surakarta. Pekerjaan sebagai pengayuh becak membutuhkan kondisi fisik yang baik agar pekerjaan dapat dilaksanakan secara maksimal karena Semakin berat penumpang atau barang yang diangkut, semakin besar pula tenaga yang dikeluarkan. Kondisi seperti ini yang mempertinggi resiko cedera pada anggota tubuh. Keluhan pekerjaan dapat diakibatkan ketidak-alamiahnya pekerjaan tersebut. Adapun keluhan yang biasa dihadapi oleh seorang pengayuh becak seperti nyeri pada lutut, nyeri pada pinggang ataupun hanya pegal-pegal akibat kelehahan yang berlebih. Namun tentu hal ini akan mengakibatkan masalah kesehatan berlanjut jika tidak ditangani dengan cepat dan tepat bisa mengakibatkan semakin parahnya keadaan. hal ini akan berkaitan dengan tim medis yang salah satunya adalah ortotik prostetik.

\section{METODE PENELITIAN}

Jenis penelitian ini adalah eksperimental dengan rancangan one group pretest-post test design. Populasi penelitian ini adalah pengayuh becak di pasar klewer Surakarta. Pengambilan sampel dilakukan dengan cara mengambil semua subjek yang memenuhi kriteria inklusi dan bersedia berpatisipasi dalam penelitian, menandatangani surat persetujuan menjadi responden (informed consent). Subjek dalam penelitian ini adalah 20 orang pengayuh becak yang mengalami nyeri lutut. Pengambilan data dilakukan pada tanggal 14 april 2017 sampai dengan 21 mei 2017. Subjek diberi penjelasan mengenai tujuan dan proses penelitian. kemudian dilakukan pengukuran nyeri pre test munggunakan VAS (Visual Analoge Scale), Subjek diberi perlakuan berupa elastic knee decker selama 20 hari selanjutnya dilakukan post test unruk mengambil hasil.

\section{HASIL PENELITIAN}

Subjek penelitian (sampel) dalam penelitian ini adalah pengayuh becak yang mengalami nyeri lutut di pasar klewer Surakarta dan sesuai dengan criteria inklusi, dengan karakteristik seperti pada tabel 1 dibawah ini.

Tabel 1

\section{Criteria Inklusi}

\begin{tabular}{lcc}
\hline Karakteristik Sampel & Min & Maks \\
\hline Usia & 43 thn & 60 thn \\
\hline
\end{tabular}




\section{PEMBAHASAN}

Dari output negative ranks atau selisih antara variabel sebelum dan sesudah yang negative sebanyak 20 observasi atau dengan kata lain terdapat 20 observasi pada variabel sesudah yang kurang dari observasi pada variabel sebelum dengan rata-rata rangkingnya 10,50. Oleh karena nilai asymp sig $=$ 0,000 yang berarti bahwa ada pengaruh sebelum dan sesudah penggunaan knee decker.

\section{KESIMPULAN DAN SARAN}

Penelitian yang dilakukan pada tanggal 14 April sampai 21 mei 2017 dengan subjek 20 orang pengayuh becak dengan nyeri lutut di pasar klewer didapatkan hasil penelitian yang bermakna pada pemberian elastic knee decker yang saya gunakan pada saat penelitian yaitu terjadi pengurangan derajat nyeri lutut dengan usia 40-60 tahun karena mekanisme kerja dari knee decker tersebut yaitu memberikan penekanan sekitar lutut dan menjaga area lutut tetap hangat. $\mathrm{P}$ : $0.00 \quad(\mathrm{p}<0.05)$. hasil ini menunjukkan bahwa terdapat pengurangan derajat nyeri antara sebelum dan sesudah diberikan perlakuan. Jadi dapat disimpulkan bahwa pemberian elastic knee decker pada penderita nyeri lutut dapat mengurangi nyeri penderita saat beraktivitas.

Saran-saran sebagai berikut:

1. Perlu dilakukan penelitian sejenis dengan jumlah subjek yang lebih banyak dengan tipe knee decker yang lain seperti kne decker yang menggunakan plat sehingga dapat digeneralisasikan.

2. Penelitian selanjutnya harus lebih spesifik terkait subjek penelitian seperti memperhatikan criteria inklusi yang akan ditetapkan pada subjek yaitu berat badan dan beban yang diangkut oleh pengayuh becak tersebut agar penelitian lebih valid dan dapat diaplikasikan.

\section{DAFTAR RUJUKAN}

AHCPR., 1992; Skala identitas nyeri numerik; Diakses tanggal 28/08/16, dari http://www. konsepdasar-nyeri.html

Alodokter., 2016; Pinnecle orthopaedic group; Diakses tanggal 07/09/16, dari http://alodokter.com/search?s=

Anas, M.A., 2014; Coach educators penanganan cedera lutut melalui masase; Diakses tanggal 29/08/16 dari

http://coacheducators.blogspot.co.i $\mathrm{d} / \mathrm{m}=1$

Anonim., 2014; Nyeri lutut; Diakses tanggal 18/01/16, dari http://kamuskesehatan.com/arti/nye ri-lutut/

Clancy, McVicar., 1992; Nyeri, Modul universitas sumatra utara, Medan

David C. Dugdale., 2008; ADAM Pain Medications; Diakses tanggal 28/08/16, dari http://www.nlm.nih.gov/medlinepl us/ency/article/002123.htm

Departemen Kesehatan, 2008; Permenkes RI NO 269 /MENKES/PER/III/2008, Rekam Medis.

Donald, L.P.T, Miller, C.P.O, Albright, M.D, Feldick, M.D., 1978; The iowa knee orthosis; Orthotics and Prosthetics, Iowa, vol. 32 hal. 1 